\title{
Misremembering Reagan: A Decade of Cultural Dissent
}

\section{William M. Knoblauch}

Finlandia University

\begin{abstract}
Presidential legacies are constructed, and for the Republican Party perhaps no figure has benefitted from mythology, hagiography, and misremembrances than Ronald Wilson Reagan. Popularly, America's $40^{\text {th }}$ President is frequently remembered as residing over a massive economic upswing, restoring faith in the American military, and ushering in the end of the Cold War-combining to construct an image of a beloved, even visionary leader. Looking back at popular culture from the 1980s, however, paints a very different picture. From Reagan's relationship with the press, his shortcomings acknowledging struggles in the African American community, to his near-legacy shattering handling of the Iran Contra crisis, 1980s popular culture helps to remind us that Reagan was not so nearly beloved as today's pundits would have us believe.
\end{abstract}

Keywords: presidential legacies, collective memory, Ronald Reagan, popular culture

In 2010, the iconic American television comedy show, Saturday Night Live, aired a sketch entitled "Punk Band Reunion at the Wedding." In it, Fred Armisen plays a proud father of the bride who kindly asks the audience, from atop a stage filled with amps and drums, if they would indulge him as his old band performs. "Don't be embarrassed honey," he pleads jokingly, as the other band members (played by Bill Hader, Ashton Kutcher, and Dave Grohl of the Foo Fighters - that night's musical guest) take the stage. One member jokes, "Go easy on us...it's our first gig since 1983." What follows is a hardcore punk song with screaming vocals. "When Ronald Reagan Comes Around / He brings the fascists to your town," Armisen yells while storming the room and breaking tables and dishes; with another lyric, he even challenges Reagan's first (and short lived) Secretary of State Alexander Haig to a "fist fight." 
The skit's premise, that the now-adult members of Generation X still clung to their youthful disdain for Reagan, garnered laughs. But, to what extent did this skit resonate with younger viewers? In the years since his presidency, Reagan's legacy has improved like almost no other; until recently, politicians left and right were more likely to applaud our fortieth president than not. Just consider Time Magazine's Feb. 7, 2011 cover story, "Why Obama [Hearts] Reagan, and What He's Learned from Him."' Indeed, disdain depicted on Saturday Night Live - one shared by many in the 1980s beyond the punk scene - has been overshadowed by constructed narratives claiming Reagan's instrumental role in ending the Cold War. This myth, the myth of Triumphalism some call it, also neglects Reagan's domestic hurdles, which were many. They included dismal relations with the African American community, nuclear fearmongering, a cruel latency in addressing the AIDS epidemic, and his role in the Iran Contra scandal. Instead, in much of America's political and popular imagination, Reagan remains the classic pragmatic conservative, the standard-bearer for a Republican party which had long proclaimed that it stood for small government, balanced budgets, and individual freedom.

Although many presidents' approval ratings improve after leaving office, contemporary remembrances of Reagan benefit from well-crafted political constructions. Since 1997, political activist Grover Norquist has led the Ronald Reagan Legacy Project, which aims to honor "the $20^{\text {th }}$ century's greatest president with a memorial in every county in America." Thus far, Norquist has reached 21 states, with examples varying in size and grandeur, including the Ronald Reagan Elementary School in New Berlin, Wisconsin; the Ronald Reagan Veteran Memorial Building (American Legion post \#384) in San Francisco; and the Ronald Reagan Washington National Airport in Arlington, Virginia. ${ }^{2}$ Through these efforts, and the educational propaganda coordinated with them, Reagan has become an even more iconic symbol for the Republican Party. Complicating issues, any critiques of these

1 The author would like to thank Annie Wills, Lucas Vick, and Terry Hainstock for investigating some of these examples in our America in the World seminar. On Time Magazine, see: http://content.time.com/ time/covers/europe/0,16641,20110207,00.html (accessed 11/19/2019).

2 See The Ronald Reagan Legacy Project online, http://www.ronaldreaganlegacyproject.org/ (accessed 12/19/2019); for a detailed take on these efforts, see Niels Bjerre-Poulsen, "The Road to Mount Rushmore: The Conservative Commemoration Crusade for Ronald Reagan" in Cheryl Hudson and Gareth Davies (eds.), Ronald Reagan and the 1980s: Perceptions, Policies, Legacies (New York: Palgrave MacMillan, 2008), 209-228. 
memorials might be seen in bad taste considering the public's knowledge of Reagan's ugly final battle with Alzheimer's. Cared for by his wife Nancy, and shut off from the outside world since the mid-1990s, Reagan's funeral procession in 2004 garnered an outpouring of patriotic remembrances the likes of which Americans had not seen since the Kennedy Assassination. In the words of author Sarah Vowell, herself no fan of Reagan: "His ghastly, slow death from Alzheimer's disease, deprived any detractor with half a heart" of any final, lasting criticism. ${ }^{3}$

In addition to public displays and remembrances, the literature surrounding Reagan's legacy is largely laudatory. In foreign policy circles, some camps applaud Reagan's role in winning the Cold War; others note his pragmatism when dealing with General Secretary Mikhail Gorbachev. ${ }^{4}$ Regarding domestic policies, some works examine the entirety of the $1980 \mathrm{~s}$ with Ronald Wilson Reagan as a central, indispensable figure, the sole person who personified a decade's culture and politics. ${ }^{5}$ A third camp, not surprisingly, is more critical. These authors focus on the backlash to Reagan's policies, but they largely do so by examining underground or DIY cultures, especially via the mediums of punk music, grassroots organizations such as the Nuclear Freeze campaign, or identity politic movements of the decade. $^{6}$ This essay, however, uses another methodology. Instead of recapping underground protest culture of grassroots movements or punk communities - the archives of which are perhaps more sprawling than their actual impact-it examines examples of 1980s pop culture to reveal a public ill at ease with Reagan. Indeed, as Gil Troy confirms in his book Morning in America, "the opposition to Reagan was more intense than remembered."

3 Sarah Vowell, The Wordy Shipmates (New York: Riverhead Books, 2008), 66.

4 On the Triumphalist School, see Peter Schweizer, Reagan's War: The Epic Story of his Forty-Year Struggle and the Final Triumph over Communism (New York: Doubleday Press, 2002); for a recent challenge to this viewpoint, see Beth A. Fischer, The Myth of Triumphalism: Rethinking President Reagan's Cold War Legacy (Lexington, KY: University Press of Kentucky, 2020);

5 Gil Troy, Morning in America: How Ronald Reagan Invented the 1980s (Princeton: Princeton University Press, 2005); John Ehrman, The Eighties: America in the Age of Reagan (New Haven: Yale University Press, 2005); Robert M. Collins, Transforming America: Politics and Culture During the Reagan Years (New York: Columbia University Press, 2007).

6 See Bradford Martin, The Other Eighties: A Secret History of America in the Age of Reagan (New York: Hill \& Wang, 2011); William M. Knoblauch, Nuclear Freeze in a Cold War (Amherst, MA: University of Massachusetts Press, 2016); Kevin Mattson, We're Not Here to Entertain: Punk Rock, Ronald Reagan, and the Real Culture War of 1980s America (Oxford: Oxford University Press, July 2020).

7 Gil Troy, Morning in America, 147. 
That opposition is reflected in the 1980s pop culture examples that follow.

For this study, I have adopted the methodological approach of the late Paul Boyer who, in his atomic-themed work By the Bomb's Early Light, argued: "If a scholar a thousand years from now had no evidence about what had happened in the United States between 1945 and 1985 except the books produced by the cultural and intellectual historians of that era, he or she would hardly guess that such a thing as nuclear weapons had existed." A similar argument applies to Reagan's tenure as President. More closely after his tenure, a handful of critical works on Reagan appeared; however, if only viewed through the lens of more recent books by political and foreign policy historians - a few outliers aside-Reagan's legacy shines. ${ }^{8}$ Looking back instead at some examples in 1980s popular culture, however, reveals a much more critical appraisal. While this study is nowhere near as ambitious as Boyer's, and fixates on a different aspect of Cold War culture than nuclear fear, the sentiment remains: To get a more balanced view of Reagan's Presidency, popular culture matters.

\section{Reagan and the Press}

A President's public perception has much to do with their relationship with the press, and Reagan was no exception. During his tenure, the American press was quite complimentary to Reagan, especially compared to the criticisms and hard questions lobbied at the last elected Republican President, Richard Nixon, who just seven years prior to Reagan's presidency resigned the office in disgrace due to Watergate. Indeed, until the Iran Contra scandal, the press had comparatively been so easy on Reagan as to prompt journalist Mark Hertsgaard, who was then penning a book about the press' relationship with the president, to entitle his work On Bended Knee. ${ }^{9}$ Part of their admiration came from Reagan's grace in surviving an assassination attempt. Just a few weeks into his presidency, a deranged John Hinkley shot Reagan outside of a Washington D.C. hotel. In the moments that followed,

8 Some critical appraisals of Reagan's policies in Latin America include Mark Danner, "The Truth of El Mozote" in The New Yorker, Dec. 6, 1993; Walter LaFeber, Inevitable Revolutions: The United States in Central America (New York: W.W. Norton \& Company, 1993); on domestic mishaps, see Haynes Johnson, Sleepwalking Through History: America in the Reagan Years (New York: W.W. Norton and Company, 1991).

9 See Mark Hertsgaard, On Bended Knee: The Press and the Reagan Presidency (New York: Farrar Straus Giroux, 1988). 
Reagan played the part of a hero expertly. He walked into the hospital on his own accord (despite having a bullet lodged but one inch from his heart), quipped to his concerned wife a famous line from boxer Jack Dempsey"Honey, I forgot to duck" - and joked with surgeons that he hoped they "were all Republicans." Such humor, as conveyed by the press, further endeared Reagan to many Americans. ${ }^{10}$

Even if admiration was warranted, more than a few cultural commentators took umbrage with the press' almost too easy relationship with Reagan. Throughout the decade, no single publication was more dogged in critiquing this relationship than Gary Trudeau's left-leaning political comic Doonsbury. In serialized cartoons appearing in numerous American newspapers, Doonsbury repeatedly featured scenes from the White House pressroom, with Reagan speaking just out of frame. Almost none of these strips were complimentary. In one example, news reporters keep deferring their questions to the next reporter politely until someone finally asks an actual question: "I'd like to ask you if you really think it's possible to reconcile deep tax cuts, massive military spending and a balanced budget without having to use drugs?" Immediately, his colleagues explode at him: "Hey, C'mon Roger, that's a very negative question!" and "Yeah, Roger, give the President's policies a fair chance, for Pete's sake!" In another pressroom meeting, after deferring to Reagan's councilor Edwin Meese for multiple questions, Reagan finally chimes in: "Gosh fellas, don't you have any questions for me?" To which one reporter humbly responds, "Uh...how was your ride today, sir?" Reagan's free pass with reporters was a common gripe for Trudeau; one Doonsbury strip opens with: "Ladies and Gentlemen, the President of the United States... and let's go a little easier on him this time, okay?"11

Another series of Doonsbury strips made fun of Reagan's simplistic solutions to American problems. One in particular featured a long shot of the White House residency, with talk bubbles signifying conversations between Reagan and his wife Nancy. This time, Trudeau reflected on Reagan's alarmingly low first term approval ratings - reaching a nadir of just 35\% in

10 Haynes Johnson, Sleepwalking Through History, 159-162.

11 These comics can be found in the collection Doonesbury Dossier: The Reagan Years (New York: Holt, Rinehart and Winston, 1984); unfortunately, this collection has no page numbers. Fortunately, an online archive of Doonesbury cartoons can be accessed at https://www.washingtonpost.com/doonesbury/strip (accessed 12/19/2019). 
January 1983, during the depths of the Reaganomics-driven recession-but simultaneously he aptly summarized the challenges then plaguing the nation. Here, First Lady Nancy chides Reagan for again sleeping in ("Ronnie? It's 9:30 dear. Time to get up."). In response, Reagan goes on a tirade:

\footnotetext{
"It's those darn polls Nancy. The American People are turning against us. And it's not just Blacks and Women anymore. I don't understand it. I've done everything I promised I would do. The people voted for a country club presidency, and that's what I've given them. I promised to make the rich richer. I promised not to balance the budget on the backs of defense contractors. I promised not to pamper the environment. I promised a new Cold War. And I delivered! The American voters wanted simple answers, and I gave them to them. Now they say they'd rather have Jobs! Why can't they make up their minds? I tell you, I'm about out of patience!"12
}

This quote lays out the series of challenges and critiques Reagan faced in his first term which cultural commentators exposed to the American public. Indeed, as Trudeau lists, some of Reagan's first and harshest critics came from the African American community.

\section{Reagan and the African American Community}

"The Reagan Recession" of the early 1980s not only propelled a new wave of Democratic representatives into Congress; it also seemed to disproportionally hurt urban African American communities. Urban crime rates which had been rising since the late 1960s peaked in the early 1980s; in 1981 alone, urban crime accounted for twenty-two thousand deaths nationwide. Rhetoric about improving inner-city life inextricably had twinges of racial overtones; it didn't help that on the campaign trail Reagan frequently blamed "Welfare Queens" for scamming the social safety net, thereby implicitly scapegoating African American mothers for abusing the welfare system. Amidst accusations of insensitivity towards the Black community, Reagan thundered "This administration is totally colorblind," but many commentators weren't having it. In the seventh annual assessment of the "State of Black America," statistics showed alarming realities: African American unemployment had reached sixteen percent, with teenage unemployment in that community hovering near fifty percent. ${ }^{13}$ White House policy memos soon circulated expressing concern about the "perception 
in the Black community that this Administration is closing its doors to Blacks," a perception made plain in Reagan's disastrous 1981 delivery to the NAACP, where charm and a well-written speech did little to gain the President favor. Throughout two terms, Reagan's team largely ignored issues of race when campaigning, thereby consciously skewing the electorate and accepting low support from black voters. ${ }^{14}$

It was this perception of Reagan as oblivious to the African American community's struggles in the 1980s that made him ripe for hip hop parody. Rap had recently emerged from the Bronx as a vibrant new artform, one that was almost solely the purview of young inner-city African Americans. What could be funnier than a white septuagenarian politician attempting it? Numerous acts pretended to have Reagan rap, and not just for parody, but to deliver political critiques. The first was a collaboration between Cleveland DJ Bobby Magic and Reagan impersonator Rich Little. Entitled "The President's Rap," it featured clips of Little's 1981 comedy LP The First Family Rides Again which depicted Reagan as absent minded and dithering, as the Tom Tom Club's hit "Genius of Love" plays in the background. In May of 1982, Billboard noted that "The President's Rap" had "become the most talked about record in this market." 15 Imitators followed. Mark Moseley's "Ronnie's Rap," (recorded under the moniker "Ron and the D.C. Crew") included unflattering lyrics such as: "Well, I get up in the morning, and I have some toast / And Nancy and I take a ride up the coast / I'll sign a bill, then take a nap / This is what I call my Presidential Rap!" It's hardly high art, but in 1987 "Ronnie's Rap" made it all the way to \#93 on the US pop charts. ${ }^{16}$

Trudeau took his own swing at a Reagan rap with "Rap Master Ronnie," a song and music video originally released in 1984 which painted the president as nothing short of racist. In the video's opening, three black teens approach Reagan's limousine, seemingly startled that the President would come to their neighborhood. Exiting the limo as a beat begins to play, Reagan - this time played by Robert Schmidt-exclaims that he's really in a "grove" now (the Secret Service agent corrects him: "That's 'Groove' Sir"). The racism increases from there. After admitting that he only needs "ten

15 “Rap Disk Puts First Family on Dance Floor," Billboard, May 1, 1982, p. 3.

16 This particular Reagan Rap was born of a Florida radio station morning show's parody, but was later released as a single on Profile Records. See https://genius.com/Ron-and-the-dc-crew-ronnies-rap-lyrics, accessed 02/01/2020. 
percent" of the black vote, Reagan congratulates himself for being "the man who signed your welfare checks." With iterations on cable television, Music Television, and a LP release, "Rap Master Ronnie" reflected Reagan's issues with the African American electorate. ${ }^{17}$ Trudeau rehashed the song for the retrospective Rap Master Ronnie: A Report Card, which aired on Cinemax in 1988 just as Reagan's term was winding down. In this update, Trudeau continued his attacks on the president, now played by Jim Morris. ${ }^{18}$ Repeating Reagan's limo arrival in the inner-city, this rap begins with some alarming language: "Hey there Zulus / Gotta Confide / Rappin' Ron Reagan is on your side." Soon, the Secret Service agents get involved: "Don't be throwing rocks / running with the mob..." Reagan refrains: "That nice police informant just be doing his job." Secret Service: "Don't be burning busses / don't be leaving reason..." Reagan: "Try to keep it cool until after tourist season." He concludes with: "Let wiser heads take charge of your affairs; the right to vote is no answer to your prayers." The skit ends with black teens signaling not so subtly for the president to get out of their neighborhood.

\section{Nuclear Fears}

If in the early 1980s Reagan's domestic challenges included discord with the black community, his administration's rhetoric over nuclear weapons alarmed Americans of all walks of life. While campaigning in 1980, many of Reagan's supporters and advisors bragged about America's ability to fight and win a nuclear war-a stark difference from the 1970s rhetoric of détente and attempts to lower global nuclear fear. Once in office, Reagan oversaw the largest peacetime military buildup in American history, with defense spending increasing every fiscal year, contributing $\$ 2.7$ trillion to the deficit after eight years. Much of these funds went to an intensifying nuclear arms race with the Soviet Union; in response a new antinuclear movement, the nuclear freeze campaign, surged in popularity. It did not take long for popular culture to reflect the fears of these antinuclear activists. ${ }^{19}$

17 "Rap Master Ronnie" was made into multiple sketches. It was first recorded by "Reathel Bean and the Doonesbury Break Crew," then with another Reagan look alike, Robert H. Schmidt, and finally with Jim Morris. See Kenneth Bredemeier, "Rap Master Ronnie," Washington Post July 12, 1984; Frank Rich, "Stage: Partisan Revue, 'Rap Master Ronnie'," New York Times, Oct. 4, 1984.

18 Timothy Marx (producer); Gary Trudeau and Elizabeth Swados (creators), Rap Master Ronnie: A Report Card. 14 February 1988. Accessed January 28, 2020, online at https://www.youtube. com/watch?v=cE_ xbQGWbog.

19 William M. Knoblauch, Nuclear Freeze in a Cold War, 1-6. 
Domestically, the biggest antinuclear event of the decade came on November 20, 1983, when ABC aired the made-for-TV movie The Day After. Based in and around Lawrence, Kansas, the film depicts the everyday lives of Americans as tensions escalate in Europe between the U.S. and the Soviet Union. Some thirty minutes into the film, ICBMs (Intercontinental Ballistic Missiles) emerge from their underground silos, sending panicked citizens for cover. Soon, the Soviet bombs arrive, and those who live through the initial blasts struggle to survive the aftermath. In the wake of the bombs, sickly citizens grapple with a broken-down society in which radiation illness, lawlessness, and despair slowly kill those unfortunate enough to see "the day after" a nuclear war. While ABC played down the political overtones of such a film, The Day After's director, Nicolas Meyer, was blunter, stating that his goal was not to entertain, but to "clobber sixty million people over the head" with an antinuclear message..$^{20}$

The film aired at an auspicious time, as 1983 was a year filled with tense geopolitical developments. In March, Reagan had christened the Soviet Union an "Evil Empire," and two weeks later announced an ambitious nuclear defense system, the Strategic Defense Initiative (SDI, or "Star Wars" to its detractors), which threatened to further destabilize the Cold War nuclear standoff. The Day After, produced with these developments in the backdrop, aired just two months after the Soviets shot down a civilian airliner, KAL 007, killing 269 passengers including a U.S. Congressman, and just weeks after the U.S. invaded the Caribbean Island of Grenada. For these reasons, as well as an aggressive marketing campaign, The Day After became something of a media event, with an estimated 100 million Americans tuning in, and ABC airing a special Nightline roundtable after the film to discuss the state of nuclear affairs. In newspapers across America, conservative administration officials attempted to "spin" the President's previously harsh rhetoric with a new slogan: that a "nuclear war cannot be won and must never be fought." Clearly, public backlash against Reagan's nuclear buildup was palpable, and seldom after did any administration official brag about winning a nuclear war. ${ }^{21}$

20 Note that a forthcoming documentary from director Jeff Daniels, entitled The Television Event, is set to be released sometime in 2020, and features interviews with the director and Reagan Administration officials; Knoblauch, Nuclear Freeze in a Cold War, 63.

21 For a full analysis of The Day After and its effect on the administration, see Knoblauch, Nuclear Freeze in a Cold War, 60-78. 
Nuclear fear was not relegated to America alone; in Europe, the "Euromissile Crisis" sparked popular protest. The roots of the crisis date back to 1977 , when the Soviets deployed intermediate range (nuclear) ballistic missiles throughout the Eastern Bloc, prompting many NATO countries to look to the United States for assistance. By 1983, that assistance was set to arrive in the form of U.S. medium range ballistic (Pershing II and cruise) missiles. Now living with the prospect of a Soviet-American nuclear war that might begin in their backyards, the European Nuclear Disarmament (E.N.D.) movement reached a fever pitch. Widespread fears of nuclear war seeped into the supportive UK music community. Serendipitously for these artists, just a few years previous a new music platform-Music Television, or MTV - transformed how music was marketed. In fact, the channel largely relied on British "New Wave" acts to fill daily playlists - the very same acts who would cross the Atlantic via MTV to criticize Reagan in songs and music videos in millions of American homes.

The appearance of Reagan's visage in 1980s MTV music videos owes much to a politically-themed British television show that premiered in 1984: Spitting Image. The show used grotesque puppets to poke fun at leaders such as Margaret Thatcher and, of course, Ronald Reagan. The British dance band Frankie Goes to Hollywood used the voice actor from Spitting Image, Chris Barrie, to impersonate Reagan throughout their 1984 album Welcome to the Pleasuredome. In the song "War," Reagan muses about a war that had apparently broken out under his watch - a very serious critique influenced by the fears of the Euromissile Crisis. The band then chose to lob another volley at Reagan in the music video for their hit "Two Tribes." This MTV video features a fist fight between a faux-Reagan and then Soviet Premiere Constantine Chernenko, a clear metaphor for the superpower contest that seemed to be heating up in the early 1980s. As the fight intensifies (at one point Reagan bites Chernenko's ear), other world leaders get involved, and at the video's conclusion, the earth explodes, apparently from a nuclear war. ${ }^{22}$

Spitting Image's influence continued with another group, Genesis, and their 1986 video for "Land of Confusion." It features the Reagan puppet from Spitting Image (again voiced by Chris Barrie) who, upon going to bed at the early hour of 4:30 pm, has a series of nightmares featuring equally grotesque puppets of world leaders. After enduring nightmare after night-

22 For a more in depth analysis, see William Knoblauch, “'Will You Sing About the Missiles?': British Antinuclear Protest Music of the 1980s" in Eckart Conze, Martin Klimke, and Jeremy Varon (eds.), Nuclear Threats, Nuclear Fear and the Cold War of the 1980s (New York: Cambridge University Press, 2017). 
mare -and at one point donning a Superman costume-a sweat-drenched Reagan finally awakes, and in attempting to summon a nurse, accidently hits the "Nuke" button instead. As the video concludes, a mushroom cloud arises in the background. To call the video unflattering would be an understatement, and the fact that "Land of Confusion" peaked at number 4 on the U.S. charts and won a Grammy award for "Best Concept Music Video" suggests that it had a wide reach within American markets. ${ }^{23}$ But even if middle America was learning that many overseas saw their president as a bumbling old man, they were less ready to face frightening new domestic realities, especially of an emerging disease that was killing hundreds of young homosexual men. It was Reagan's botched response to the growing AIDS epidemic that earned him serious backlash.

\section{AIDS}

In the early 1980s, cases of a "gay plague" arose in San Francisco. Once the 1960s epicenter of the American counterculture, San Francisco had become, two decades later, ground zero for the gay community. The city featured dozens of bath houses that catered to a sexually active clientele. By 1981, however, these men faced a frightening new disease. That year, the New York Native warned its largely gay subscribers that the yet unnamed illness was not just cutting down young men in San Francisco anymore; it had made its way to the east coast. By 1982, with cases on the rise, the medical community christened it the Acquired Immune Deficiency Syndrome, or AIDS. Because so many of its early victims were gay men, the conservative Reagan administration paid little attention to the crisis; in fact, at times it was openly hostile to the gay community. Patrick Buchanan, who became Reagan's Communication Director (1985-1987) wrote in 1983: "The poor homosexuals; they have declared war upon nature, and now nature is exacting an awful retribution.” Moral Majority founder Jerry Falwell pronounced on TV that when gays "violate moral health and hygiene laws, you reap the whirlwind. You cannot shake your fist in God's face and get away with it." 24

Any question as to whether or not the Reagan Administration would share such biases were confirmed in 1982 by Press Secretary Larry Speaks. 
When asked about reports from San Francisco of a "gay plague," after a chorus of chuckles from the press corps he simply responded with: "I don't have it. Do you?" 25 If Speaks' comments seem horrifically tone deaf today, Reagan's lack of response on this emerging epidemic was outright deafening. It wasn't until 1985 when an old Hollywood friend, actor Rock Hudson, died at the age of 59 from complications of AIDS that Reagan publicly recognized the disease. At that point, an estimated 5,000 people had perished from AIDS. In New York City, the AIDS Coalition to Unleash Power (ACT UP) took to the streets in protest, shouting "President Reagan, nobody is in charge!"'26

The response from a shocked and saddened gay community was noble and considerable. No group more vigorously attempted to get the masses informed and get AIDS destigmatized via propaganda than Gran Fury. While groups like ACT-UP engaged in traditional protests and sit-ins, Gran Fury artwork sought a broader reach through provocative images in public spaces. These pieces aimed to inform citizens that AIDS was not simply a gay problem. Examples include the "For Art against AIDS" banner which featured multicultural and multi-sexual men and women kissing below the slogan: "Kissing Doesn't Kill: Greed and Indifference Do." A follow up poster, this time trying to break the stigma that only gay men could contract the disease, read "Women Don't Get AIDS: They Just Die from It." Concurrently with these provocative images in New York City, Larry Kramer's Broadway play The Normal Heart, which was based on Kramer's own experiences during the early years of the AIDS outbreak, began a strong run after receiving rave reviews. ${ }^{27}$

In markets outside of San Francisco and New York City, it took actors, writers, and pop stars with mainstream pull to spread information about AIDS to middle America. The NBC made-for-TV movie An Early Frost, about an AIDS stricken son's attempt to reconcile with his father, earned high praise in the Washington Post from contributor Tom Shales, who

25 Speaks reaction is recorded on When AIDS Was Funny, a 2015 documentary featured on Vanity Fair's website, https://www.vanityfair.com/news/2015/11/reagan-administration-response-to-aids-crisis (accessed on February 1, 2020), hereafter referenced as When AIDS Was Funny.

26 Martin, The Other Eighties, 172.

27 On ACT-UP, see Bradford Martin, The Other Eighties, 171-187; Gran Fury artwork can be found at When AIDS Was Funny; Gil Troy, Morning in America, 200-201. 
said the film was "likely to be the most important TV movie of the year." Recognizing the educational potential of this film, NBC News ran a special on AIDS immediately after it aired. Two years later, journalist Randy Shilts' book And the Band Played On, a scathing critique of a government bureaucracy's foot-dragging on the subject of AIDS, became a New York Times best seller and later a major motion picture. But there was arguably no greater catalyst in getting middle America to recognize the realities of AIDS than the case of Ryan White. ${ }^{28}$

An adolescent Indiana hemophiliac, White contracted AIDS from a blood transfusion. Only 13 at the time, he faced stigma from an ignorant superintendent who banned him from returning to school. Additionally, the local community ostracized the Whites, vandalizing their home and forcing the family to move to Cicero, Indiana, where he was more openly accepted at school. The story proved so harrowing that in 1989 a made-fortelevision film, The Ryan White Story, aired on ABC. White's grace in the face of such harassment earned him the admiration of some big names in the entertainment industry, including Elton John. He had already - alongside Gladys Knight, Stevie Wonder, and Dionne Warwick - sang a cover of "That's What Friends are For" which became the number one single of 1986, proceeds of which (some \$3 million) went to AIDS research. While many celebrities had visited White, it was Elton John's unwavering support of White and his family - going so far as to loan White's mother some $\$ 16,000$ to purchase a new house, and in his final days, standing vigil by the boy's bedside - that set John apart. The day after White's death, John performed his 1973 hit "Candle in the Wind," which he dedicated to Ryan. Such acts further publicized White's death at the young age of 18, and in 1990 even former president Reagan - the man who remained mum on the tragedy of AIDS as thousands of young men died-penned a farewell message to White that appeared in The Washington Post. ${ }^{29}$

Despite the numerous domestic and foreign policy challenges that Reagan faced in his first term, he handily won reelection in 1984, carrying all electoral votes save for Minnesota and the District of Columbia. Some attributed this victory to Reagan's experience playing to the cameras, a

28 Tom Shales, “TV Previews," Washington Post November 11, 1985.

29 Troy, Morning in America, 201. 
skillset that his opponent, Democrat Walter Mondale, lacked. Others cite the economic rebound of 1984 and the tailored, optimistic ad campaign that Reagan promoted (the iconic "Morning in America" slogan, clearly far more memorable than his 1980 slogan "Let's Make America Great Again") as the primary cause. In any case, Reagan had earned a reputation as "the Teflon President," the man whose charm and affability could disarm many critics. ${ }^{30}$ However, halfway through his second term, Reagan faced a challenge unlike any before, after news broke about a secret plan to divert funds from Iranian leaders to support anti-communist "Contras" in Latin America. Indeed, what would come to be known as the "Iran Contra Affair" threatened to tarnish Reagan's reputation permanently.

\section{Iran Contra}

Beginning in 1981, the Reagan administration actively engaged in Cold War activities targeting communism abroad, and under CIA director William Casey, overseas military engagements and covert operations were extensive. In the 1980s, U.S. secret services actively funded and trained the Mujahedeen - the Afghani "freedom fighters," among them a wealthy Saudi radical, Osama bin Laden - to kill Soviet troops that had invaded in December 1979. Rhetorically, Reagan supported the Solidarity labor movement in Poland, even after he disbanded American striking airline workers (the PATCO strike) at home, and denounced Middle Eastern terrorist groups like Hezbollah. Rhetoric turned to action in 1983, when Reagan sent Marines to Lebanon, a move that ended in tragedy, with an October barrack bombing that killed 241 servicemen. Only 48 hours later, Reagan ordered Marines to take the small Caribbean island of Grenada; this latter action was more successful, ousting a communist government and freeing numerous medical students. Perhaps it was this latter victory that emboldened the administration in its second term, as it aimed to roll back communism further, this time in Latin America. ${ }^{31}$

The roots of the Iran Contra affair date back the Iranian hostage crisis of 1979. After popular protests led to the overthrow of Muhammad Reza Shah Pahlavi, the Ayatollah Khomeini established a radical Islamic

30 Sean Wilentz, The Age of Reagan (New York: Harper Collins, 2008), 172-175.

31 George Herring, From Colony to Superpower: U.S. Foreign Relations since 1776 (New York: Oxford University Press, 2008), 866-893. 
republic. In time, Iran would support the Shia terrorist group Hezbollah, who were active in the Lebanese Civil War of 1982-83, and who held American hostages. Determined to free those hostages, Reagan's administration sought to sell arms to Iran covertly, and then direct the funds to anticommunist "Contras" in Nicaragua as they battled the communist-leaning Sandinista National Liberation Front (or Sandinistas). When Congress learned of the Contra's misdeeds, including pedaling drugs and beheading civilians, they voted on a series of amendments spearheaded by Representative Edward Boland. These "Boland Amendments" made clear that U.S. intelligence agencies were not to offer any future financial assistance to the Contras. Convinced of the righteousness of their cause, and apparently oblivious to reports that the Contras were peddling drugs and murdering civilians, Reagan proposed a workaround to the Boland Amendments, one that categorized the National Security Council as not an "intelligence agency." Therefore, Iran Contra was an attempt by the administration to find a way to continue funding the Contras and hopefully engage in hostage negotiations with Tehran. In doing so, it blatantly violated an act of Congress.

Reagan's obsession with fighting communism in "our own backyard" is reflected in graphic novelist Frank Miller's now classic The Dark Knight Returns. Primarily set in a gritty version of Gotham City (a loose stand in for New York City) circa 1986, it features Ronald Reagan as president, who Miller presents as characteristically genial in public (when asked a question about cleaning up Gotham, Reagan replies "Well, I don't think that's my bull to-my Row to Hoe, Boys...Heh...you see. That's a right big state, all its own... and its got its own solid, clear-headed Governor, yes, it does..."), but behind closed doors, the president is much more conniving. Miller's depiction of Reagan in private, in which he drops his folksy façade, turns serious, and orders Superman to fly to Latin America to fight off communists, was one of many accusations of duplicity lobbed at the president as revelations of Iran Contra became public. ${ }^{32}$

On December 6, 1986, the popular American comedy show Saturday Night Life aired a similarly-themed sketch entitled "President Reagan: Mastermind." In it, Reagan (played by the late actor Phil Hartman) vacillates between the "amiable dunce" caricature that democrats loved to deride, and a manic political genius. In public, Reagan proceeds in his familiar way:

32 Frank Miller, The Dark Knight Returns: 30 ${ }^{\text {th }}$ Anniversary Edition (Burbank, CA: D.C. Comics, 2016). There are no page numbers, but Reagan appears in "Book Three: Hunt the Dark Knight." 
plodding, genial, and generally unknowledgeable. He bumbles through a reporter's questions or kindly congratulates a visiting Girl Scout for selling a record number of cookies. Once alone with his cabinet, however, he changes, dictating arcane details of the Iran-Contra Affair. He loudly explains complex concepts to his underlings, does high-level financial computations in his head, and even speaks flawless Arabic over the phone to a political counterpart in the Middle East. ${ }^{33}$ The skit drew considerable laughs from an audience so accustomed to the former image of Reagan, with that steady small town appeal, because the thought of Reagan actually being cunning enough to coordinate an illegal government conspiracy seemed, to many Americans, hilarious. It may have been this overall perception that helped to save Reagan's reputation for the most egregious misstep of his second term.

\section{Conclusion}

Looking back at just a few examples of 1980s popular culture, we see a far more critical appraisal of Reagan than provided by many biographers or historians of the decade. From a fawning press, to a dismal relationship with the African American electorate; in mongering fears of nuclear war, to neglecting a national health crisis; and in almost getting impeached for Iran Contra, pop culture displayed some of the most critical takes on Reagan's presidency. Now, some thirty years after his tenure, Reagan's reputation remains largely glowing through an active misremembering of the 1980s, not as a decade of culture wars and political challenges, but of economic growth and conservative values.

Recognizing this discontinuity between historical fact and interpretation is all the more important during the Presidency of Donald J. Trump. This is an age in which facts are discounted if not outright ignored. Ironically, as Trump's tenure continues, Reagan's legacy will likely shine even brighter. As Trump continues to attack the press, mock reporters, tweet injuriously and speak incoherently, Reagan-even considering all the controversy of his two terms - can rightfully be seen by those both left and right in a much more laudatory light. For all of his missteps, at least rhetorically Reagan

33 See "President Reagan, Mastermind" (accessed on 10/24/2019) at: https://www.nbc.com/saturday-nightlive/video/president-reagan-mastermind/n9509. 
supported free trade, pointedly attacked the Soviet Union for human rights violations and misinformation campaigns, and in his farewell address even applauded immigrants who made their way to America - a stark contrast to the current Republican president.

That a President's legacy improves over time is hardly surprising. However, remembering Reagan has become something of an act not just of selective memory, but of political delusion. Consider other contemporary presidents who had landmark policy achievements: Richard Nixon's China gambit of the early 1970s, or Bill Clinton oversight of a long economic upswing in the 1990s. Both men, despite these events, are instantly remembered for their impeachable offenses (Watergate and the Lewinsky scandal, respectively). Yet Reagan's arguably impeachable hand in Iran-Contra, today, gets short shrift, even if at the time it was fodder for comedians and cartoonists alike. Hence, the lesson of Reagan's misremembrances becomes all the more important in the Trump era. The malleability of information on the internet combined Americans' longstanding fascination with conspiracy theories, might mean that decades from now Trump will be lauded as a great president. If so, popular culture may again act as an important corollary, a necessary reminder for future generations that many Americans reviled their forty-fifth president. 
